\title{
The Scientific System of Xi Jinping's Theory of Women's Development in the New Period
}

\author{
Ping $\mathrm{MAO}^{1, \mathrm{a}, *}$ Xi ZHANG ${ }^{2, b}$ Meiyu DENG ${ }^{3, c}$ \\ ${ }^{1}$ School of Marxism, Sichuan Agricultural University, Ya'an, 625014, China \\ ${ }^{2}$ School of Mechanical and Electrical Engineering, Sichuan Agricultural University, Ya'an, \\ 625014, China \\ ${ }^{2}$ School of Marxism, Sichuan Agricultural University, Ya'an, 625014, China \\ amaoping791225@163.com, bzhangxi2279@163.com, c1547846678@qq.com
}

${ }^{*}$ Corresponding author

Keywords: scientific system, women development, Xi Jinping, statements, new period

Abstract: Since the 18th National Congress of the Communist Party of China, Comrade Xi Jinping has made a series of important statements about the development of women in china.These statements cover the road, goal, theme, guarantee and focus work etc, which form a strict scientific system. The system is of great theoretical and practical significance to promote women's cause in the new period of China.

\section{Introduction}

The theory used by the Communist Party of China (short for CPC) to guide the women's movement is the basic principle of Marxism and its view of women. ${ }^{[1]}$ Since the 18th National Congress of the CPC, comrade Xi Jinping has attached great importance to the cause of women's development in China. Based on the reality of china, he has made a series of important statements about the development of women. These statements are rich in content, covering the road, goal, theme and guarantee, which have great theoretical and practical significance to promote women's development in the new period.

\section{The Path : The Socialist Road with Chinese Characteristics}

'Road is the first problem related to the success of our cause' ${ }^{[2]}$. In October 2013, Comrade Xi Jinping pointed out 'in every historical period of revolution, construction, and reform, our party has insisted on placing women's work in an important position, led the women's movement in China to achieve historic achievements and blazed a path for the development of women with Chinese characteristics.' ${ }^{[3]}$ This path is to adhere to the Marxist concept of women's development under the leadership of the CPC and based on China's basic national conditions, correctly recognize and exert the role of women in building socialism, achieve women's liberation, realize equality between men and women, and promote women's all-round development.This road is the most distinctive feature of the Chinese women's movement.

Currently, the distribution of rights, opportunities and resources between men and women are still unequal in the world, and society's understanding of women's potential, talents and contributions are still insufficient, various forms of discrimination against women still exist, and abuse and even destruction of women occur from time to time. But in china, the CPC and the government have always attached great importance to the development of women, and hundreds of millions of women have made great progress in keeping pace with the nation.

The data shows that Chinese women have made great progress in participating in political activities. There are 742 female representatives in the 13th National People's Congress, accounting for $24.9 \%$ of the total. Among the members of the 13th national committee of the CPPCC (Chinese People's Political Consultative Conference), 440 are women, accounting for 20.4 percent of the total. ${ }^{[4]}$ The number of female cadres in party and government institutions rose from 422,000 in the early days of reform and opening up to 1.906 million in 2017, accounting for 26.5 percent of the 
total. In 2017, the net enrollment rate of girls of primary school age was 99.9 percent, basically the same as that of boys. The female students in university and college reached 14.47 million, accounting for $52.5 \%$. The proportion of female employment has increased steadily, which has remained at about $44 \%$ since 2000 . The level of health service has improved significantly, and the maternal mortality rate has dropped from 947 million in 1989 to 196 million in 2017, meeting the requirements of the United Nations Millennium Development goals ahead of schedule. ${ }^{[5]}$ These practices have proved that only by adhering to the socialist road with Chinese characteristics can the cause of women in the new era move forward in the right direction.

\section{The Goal : To Achieve Gender-Equality and Promote Women's Development}

Gender-equality refers to the equality of dignity and value of men and women, and the equality of rights, opportunities and responsibilities between men and women. Comrade Xi Jinping said 'the pursuit of equality between men and women is great. Throughout history, without the liberation and progress of women, there can be no human liberation and progress. Every step of the development of women's cause has promoted the progress of human civilization. ${ }^{[6]}$ Gender equality is an important symbol of social civilization. The cooperation and harmony between genders is the most fundamental driving force for a society to continue prosperity and happiness.

Since the founding of the People's Republic of China, the Party and the state have attached great importance to the gender-equality. In 1954, the first Constitution of New China was promulgated, which clearly stipulated that 'Women of the People's Republic of China enjoy equal rights with men in all aspects of politics, economy, culture, society and family life. ' ${ }^{[7]}$ The fourth World Conference on Women was held in 1995, at which Comrade Jiang Zemin pointed out that "the realization of equality between men and women is an important measure of social civilization." ${ }^{[8]}$ In August 2005, China revised the Law on the Protection of Women's Rights, and for the first time incorporated gender-equality as the basic state policy. In October 2017, the 19th National Congress of the CPC included 'upholding the basic state policy of equality between men and women' in its report, further defining it as an important work for the party and the country to improve people's wellbeing in the new era.

Great achievements have been made, but there are still many difficulties. For example, the stereotype of patriarchal preference has not yet been eliminated, gender discrimination is not uncommon in social life, the proportion of women's participation in politics and government is generally low, employment discrimination still exists and so on. "The Global gender Gap report 2018" publishes the gender gap in 149 countries around the world, and China ranks 103rd as a whole.

Actually, China ranked 149th in 'the gender health and survival' index, the lowest in the world, 122nd in 'political participation', 130th in 'secondary education enrollment', 1st in 'higher education enrollment', and 1 st in 'professional and technical workers', ${ }^{[9]}$ which shows that the distribution of rights, opportunities and resources between men and women in China is still unequal. Therefore, Comrade Xi Jinping pointed out 'to achieve equality between men and women, we still need to make great efforts.We should make unremitting efforts to open up a broad road for the development of women's cause. " ${ }^{[10]}$ The key to achieving gender equality is to create a good development environment, enhance women's development ability, and attain equality of rights, opportunities and responsibilities. For example, we should abandon the traditional idea of patriarchal preference, provide more opportunities for women to participate in public activities, gradually enhance women's decision-making ability, develop women's education, and finally realize gender-equality in all social activities.

\section{The Guarantee : The Leadership of the CPC}

The leadership of the Party is the most essential feature of socialism with Chinese characteristics. The cause of women's development can not be separated from the guidance of the CPC.

In the long-term working practices, the CPC has always put the development of women's cause in an important position. In 1921, a program adopted by the Party made provisions for the admission of female party members, providing women with the opportunity to become party members. In 
1922, the 2nd National Congress of the CPC further pointed out that women should enjoy equal rights with men in politics, economy, culture and other aspects. Stepping into the 21st century, the Party and the government have included gender-equality in the national economic and social development plan, put forward a series of new tasks, and adopted measures to carry them out. Statistical monitoring data shows that more than 80 percent of the targets have been achieved ahead of schedule. China has taken the lead in achieving the UN millennium development goals and has made every effort to implement the women's goals in the 2030 agenda for sustainable development. Practice has proved that the leadership of the CPC is the fundamental guarantee for the development of women, and only under the leadership of the Party can the cause of socialist women with Chinese characteristics advance in the right direction.

Women's development is a huge systematic project, involving politics, economy, culture, society, law, ecology and many other aspects. "The Program for the Development of Women in China (2011-2020)" divides women's development into seven areas, each with many secondary indicators. For such a huge systematic project, there must be a leading force. In today's China, only the CPC can assume the role of leader of women's cause. China has the largest group of women in the world. Their progress and development not only play an important role in the economic and social development of our country, but also have a profound impact on the progress of mankind as a whole. Chinese women, who account for $1 / 4$ of the world's total number of women, are not only the most valuable human resources, but also the most important relying forces. How they play their role is directly related to the success or failure of the socialistic construction.

\section{The Theme : Realizing the Great National Rejuvenation}

The theme of Chinese women's development in the new era is to shoulder important responsibilities for the great rejuvenation of the Chinese nation.

First, fully recognize the role of women in social life. Marxism holds that "The prerequisite for the emancipation of women is their return to public service. "[11]. Therefore, women must move from the family to the society and devote themselves to social productive labor and public services in order to achieve independence. At the end of 2014, a survey on gender equality by Bain\&Company, the world's leading strategic consulting firm, found that china's female employment rate was $73 \%$, ahead of many developed countries (Australia 66\%,67\% in the UK and $62 \%$ in the United States), and was one of the highest employment rates for women in the world. Practice has proved that in China's economic and social development, the majority of women have contributed wisdom and strength, full of happiness and sense of gain. Women, like men, are the promoters of human history and the creators of social, material and spiritual progress. Women hold up half of the sky.

Secondly, recognize the role of women in the family. Women have a unique role in the family life. Comrade Xi Jinping pointed out: "we should also pay attention to the unique role of women in social life and family life, and give full play to the unique role of women in carrying forward the family virtues of the Chinese nation and establishing a good family style." [12] Since ancient times, women have been good masters of family governance, not only the managers of family wealth, but also the defenders of family stability, as well as the main implementers of family education and breeders of family virtues.

The family is the foundation of society. Family harmony is related to social harmony, related to the healthy growth of the next generation. In the new era of realizing the national rejuvenation, 'The tasks we face are even more arduous, and the goals we face are more ambitious. Therefore, it is more necessary for women in our country to contribute wisdom and strength. ${ }^{[13]}$. Women are 'half the sky', building a well-off society in an all-round way, realizing the two 'one hundred' goals and the great national rejuvenation, which require our joint efforts. Therefore, it is necessary to play a role of women's 'half the sky' and promote women's important responsibility to achieve the social and family values of women in both the family and social sectors.

\section{The Focus : To Effectively Safeguard the Legitimate Rights and Interests of Women}

The fundamental purpose of women's work is to safeguard the rights of women. Human rights 
protection is a key link in the cause of women's development, where all kinds of contradictions and problems are accumulated. Since the 18th National Congress of the CPC, Comrade Xi Jinping has made many statements on the protection of women's rights and interests, which reflects the importance attached by the Party and the state to the protection of women's rights and interests.

First of all, the state should bear the main responsibility in safeguarding the legitimate rights and interests of women. For physical and psychological reasons, women and children are the biggest victims in all kinds of unpeaceful and unsafe environments. Women and children are often more vulnerable when natural disasters or uncontrollable risks occur. In China, due to the influence of thousands of years of feudal rule, women's awareness of independent rights is weak. In 1995, the fourth World Women of the United Nations defined the strategy of gender main-streaming, which requires governments to integrate the development of women into the overall planning of economic and social development and become the primary goal of all action programmes and policies. Therefore, the government should take the initiative to assume the primary responsibility for gender mainstreaming, attach great importance to the rights protection of women and children, earnestly safeguard the legitimate rights and interests of women and children, and let every woman and child bathe in the sunshine of happiness and peace.

Secondly, women's legitimate rights and interests must be protected by the rule of law. Comrade $\mathrm{Xi}$ Jinping pointed out that 'Women's rights are basic human rights. We must incorporate the protection of women's rights into laws and regulations, and rise to the will of the state to become a norm of social behavior. " ${ }^{[14]}$ In legislation, it is necessary to clarify that 'women's rights and interests are basic human rights', and write them into laws and regulations to be embodied as operational legal norms. In law enforcement and judiciary, we must crack down on crimes against women and children and provide justice for women and children. In legal propaganda and education, it's necessary to call on everyone to study the Constitution and laws so that the people can understand the law, and consciously fight against various illegal acts.

\section{Conclusion}

$\mathrm{Xi}$ Jinping's theory of women's development has profound connotations and is a scientific system. On the basis of adhering to the Marxist view of women, he inherited and developed the women's thoughts of the leading collectives of the CPC since the founding of the People's Republic of China, according to the reality of the development of contemporary Chinese women, combined with his own working background, taking the problem as the guide, and made a lot of new statements and new conclusions on this topic. These dissertations are rich in content, covering the path, goal, guarantee, theme, foc us work etc, forming a complete set of scientific system. Analyzing the logical connection between them and sorting out the scientific connotation, it is of great theoretical and practical significance to enrich Xi Jinping's new era of socialist thought, inherit and develop Marxist views on women and solve outstanding problems in the current cause of women in China.

\section{Acknowledgements}

This paper is funded by the China Scholarship Council (CSC) and is one of the research results of the author during his visiting to the University of Birmingham.

\section{References}

[1] The Editorial Committee of the Central Committee of the Communist Party of China. Selected Works of Jiang Zemin (Volume I) [M]. Beijing: People's Publishing House. 2006-08

[2] The editorial group of the book. Xi Jinping talks about governing the country [M]. Beijing: Foreign Languages Press. 2014-10

[3] [13] Xinhua News Agency, Xi jinping stressed during a group talk with the new leadership of China Women's Federation: adhere to the basic state policy of gender equality and give full play to the great role of women in China [N]. People's Daily

[4] CCTV News. Xi Jinping encouraged them to write ,beautiful life ${ }^{e e}$ [EB/OL]. CCTV. http:/news.cctv.com/2019/03/08/ARTIgLf3FMD1S xHJaFK0 fdbr190308.shtml

[5] China Women's Daily reporter. Spring Breeze forty years to achieve her career - a review of the 
development of women's career in China during the 40 years of reform and opening up [N]. China Women's Daily. 2018-12-18:07

[6] [10] [14] Xi Jinping. Promoting women's all-round development, building and sharing a beautiful world—_-Speech at the Global Women's Summit [N]. People's Daily.2015-09-28:03

[7] The constitution of the People's Republic of China (1954). [EB/OL]. China National People's Congress Network. http $/ /$ www.npc.gov.cn/wxzl/wxzl/2000-12/26/content_4264.htm

[8] Jiang Zemin. Speech at the Welcome Ceremony of the Fourth World Conference on Women. [EB/OL]. People's Network. http//www.people.com.cn/GB/99013/99043/6188135.html

[9] "The Globe Gender Gap Report 2018", [EB/OL]. https:/www. we forum.org/reports/the-global-gender-gap-report-201

[11]The compilation and translation bureau of works of Marx, Engels, Lenin and Stalin of the CPC Central Committee. Selected works of Marx and Engels (vol. 4) [M]. Beijing: people's publishing house. 1995-06:72

[12]Literature research office of the CPC Central Committee. Excerpt from xi jinping's discussion on socialist political construction [M]. Beijing: central literature publishing house.2017-08 